\title{
A parametric building energy simulation case study on the potential and limitations of passive design in the Mediterranean climate of Malta
}

\author{
Heinrich Manz ${ }^{1,2, *}$, Daniel Micallef ${ }^{1}$, Simon Paul Borg ${ }^{1}$, and Vincent Buhagiar ${ }^{1}$ \\ ${ }^{1}$ Department of Environmental Design, Faculty for the Built Environment, University of Malta, Msida, MSD 2080, Malta \\ 2 Institute of Building Technology and Energy, School of Engineering and Architecture, Lucerne University of Applied Sciences \\ and Arts, Technikumstrasse 21, 6048 Horw, Switzerland
}

Received: 20 July 2018 / Accepted: 22 September 2018

\begin{abstract}
The present case study sets out to investigate the potential and limitations of passive building design in a typical Mediterranean climate. The Maltese Islands were taken as the case study location. Assuming a fully detached, cuboid-shaped, generic multi-storey office building, one representative storey was modelled by means of the building energy simulation code WUFI ${ }^{\circledR}$ Plus. Thermal comfort was analysed based on the adaptive acceptable operative room temperature concept of EN 15251 for buildings without mechanical cooling systems. Assuming neither artificial heating nor cooling, the free-running operative room temperature was evaluated. By means of a parametric study, the robustness of the concept was analysed and the impact of orientation, window to wall area ratio, glazing, shading, thermal insulation, nighttime ventilation and thermal mass on the achievable level of thermal comfort is shown and discussed. It is concluded that in a well-designed building and by means of decent insulation (present case: $U_{\text {wall }}=0.54 \mathrm{~W} /\left(\mathrm{m}^{2} \cdot \mathrm{K}\right)$ ), double glazing, variable external shading devices and passive cooling by nighttime ventilation, a high level of thermal comfort is achievable in this climate using only very minor amounts of energy for artificial heating and cooling or possibly even none at all.
\end{abstract}

Keywords: passive design / building energy simulation / nearly zero energy building (NZEB) / adaptive thermal comfort / nighttime ventilation / Mediterranean climate

\section{Introduction}

Buildings account for $40 \%$ of the total energy consumption in the European Union and, therefore, reduction of energy consumption and the use of energy from renewable sources in the buildings sector constitute important measures needed to reduce the EU's energy dependency and greenhouse gas emissions [1]. In Malta, a small archipelago on the $36^{\circ}$ parallel of latitude in the central Mediterranean Basin with a total population of 445,426 [2] and the most densely populated EU member state $\left(1410 / \mathrm{km}^{2}\right)$ [3], the building sector constitutes about 35\% to the total energy consumption [4] with cooling contributing more than heating [5], due to the prolonged summer season. In offices, space cooling is the main consumer, in dwellings it is domestic hot water [6]. Given that Malta only joined the European Union in 2004, the transposition of the EPBD materialised soon enough in 2006. This was subsequently

\footnotetext{
* e-mail: heinrich.manz@hslu.ch
}

revised in 2015, with maximum thermal transmittances for non-dwellings through external walls, roofs and windows defined to be 1.57, 0.4 and $4.0 \mathrm{~W} /\left(\mathrm{m}^{2} \cdot \mathrm{K}\right)$, respectively [7].

Given Malta's multi-layered history and the extensive historic building stock, traditional building technology has been replicated almost automatically into modern buildings, comprising monolithic materials providing thermal mass, yet with no insulation, typically single glazing and external louvers as traditional shading device. As a result, thermal comfort in many buildings is poor, with indoor temperatures between roughly $14^{\circ} \mathrm{C}$ in winter and $30^{\circ} \mathrm{C}$ in summer being quite common, unless energy for heating and cooling is used. Heating is usually catered for by means of small decentralised mobile gas or electric heaters, although since the last decade heat pump split airconditioning units, which can be employed for heating and cooling, are being preferred, and due to their higher efficiency and low capital cost, these have become widespread in Maltese households and small offices. Centralised space conditioning systems are very popular in large-scale office buildings, but typically uncommon in dwellings. 
Given the climate of the Maltese archipelago, with mild winters, hot summers and an annual mean temperature of $18.9^{\circ} \mathrm{C}$ [8], which results in mostly relatively small differences between the exterior and comfortable interior temperatures, the external boundary conditions appear to be favourable for nearly-zero energy buildings (NZEB).

However, not least given by the small size of the country, the scientific literature on how to minimise the energy demand for heating and cooling of Maltese buildings is limited to only a few research papers. Among the literature published on the subject, Borg et al. [9] investigated by means of building energy simulation the effects of the use of insulation in a multi-storey residential building. Caruana [10] showed the impact of different glazing apertures on the thermal performance of buildings. Gatt and Youssif [11] published a case study of a small hotel in order to analyse the possibilities of zero $\mathrm{CO}_{2}$ buildings. Micallef et al. [12] investigated the cross-ventilation of a room in a courtyard building by means of CFD and Buhagiar and Jones [13] both showed that the ventilation flow rate increases with increasing building height, where the flow is directed from outside the building into the courtyard. Separately Buhagiar and Jones [14] also demonstrated the potential of natural ventilation in cooling courtyard buildings in a Mediterranean climate.

Passive design strategies such as appropriate window to wall ratios, efficient shading and passive cooling by nighttime ventilation among others have proven to be effective in numerous studies and applications. However, optimisation of passive design in order to maximise thermal comfort and to minimise energy demand for heating and cooling strongly depends on the respective local climate. Chen et al. [15] optimised passively designed buildings in the hot and humid climate of Hong Kong, China, by means of simulation and stressed the importance of passive design for achieving sustainable buildings. Gong et al. [16] optimised passive design measures of residential buildings in 25 representative cities of China, named the passive design approach the most economical effective strategy and defined seven passive design zones in China. Khambadkone and Jain [17] developed an analysis tool for investigating the potential of passive cooling and heating strategies in Indian climates, demonstrated its application in case study locations of New Delhi, Bhopal and Hyderabad and concluded that natural ventilation is an effective strategy for all three areas. Friess and Rakhshan [18] reviewed passive envelope measures for improved building energy efficiency in the hot climate of the United Arab Emirates and stressed the particular importance of glazing and natural ventilation. Mirrahimi et al. [19] studied the effect of the building envelope on thermal comfort and energy saving for high-rise buildings in the hot-humid tropical climate of Malaysia. The impact of geometry, external walls, roofs, glazing area, natural ventilation and shading devices on thermal comfort and energy consumption was shown. Santamouris and Kolokotsa [20] reviewed passive cooling techniques such as ground cooling, evaporative cooling and nighttime ventilation. The various technologies were compared and their contribution towards energy efficiency and users' comfort analysed. Artmann et al. showed the performance of passive cooling by nighttime ventilation by means of simulation and experimental validation [21], the climatic potential of European locations for this technique [22] and the impact of different system parameters on overall efficacy [23].

Silva et al. [24] studied the energy performance of green roofs in the Mediterranean climate of Lisbon, Portugal, by means of building energy simulation using EnergyPlus as well as experimental validation. They concluded that energy saving can be achieved in roofs with little or no insulation, where the savings become marginal for highly insulated constructions. Ascione et al. [25] designed a single-storey building in the Mediterranean climate of Southern Italy and claimed that the targets for a NZEB were achieved. Additionally, the authors stressed that there is no unique solution to design a NZEB for Mediterranean climates. Buonomano et al. [26] used an in-house building simulation tool written in MatLab in order to optimise a NZEB, which includes offices and exhibition premises, to be built in Naples, Italy, and claim that very low heating and cooling energy requirements were achievable (3.9 and $6.7 \mathrm{kWh} / \mathrm{m}^{2} \mathrm{yr}$, respectively), which were covered by solar energy. Michael et al. [27] investigated natural ventilation for cooling of vernacular buildings in the Mediterranean climate of Cyprus by means of a field study. The results showed that nighttime ventilation is the most effective strategy for passive cooling in vernacular dwellings during the hot summer period, compared with other ventilation strategies. Salvati et al. [28] studied the effects of urban compactness on the building energy performance in the Mediterranean climate taking the urban heat island intensity and the availability of solar radiation into account. They reasoned that compact urban textures are more energy efficient than less dense urban patterns in this climate. Mora et al. [29] analysed data from the Calabria region in Italy and found that not only climate and physical building characteristics are important as regards energy building performance but also that socioeconomic and behavioural variables of occupants can play a significant role.

In the light of the numerous passive design studies carried out for a variety of locations worldwide, the present research sets out for a systematic building energy simulation study on the effect of passive design strategies in the Mediterranean climate of the Maltese archipelago in order to understand the potential and limitations of this concept in this particular climate, which is also common to other territories.

\section{Method}

\subsection{Climate of the Maltese archipelago}

According to the Köppen climate classification, the climate on the Maltese archipelago is a temperate climate and is labelled as Mediterranean climate or dry summer climate [30]. This climate is typical for the Mediterranean Basin and is characterised by rainy winters and dry, warm to hot summers. The Mediterranean climate is also found in several regions outside the Mediterranean Basin such as California (United States), Australia, South Africa, Western and Central Asia and in Central Chile. To be 


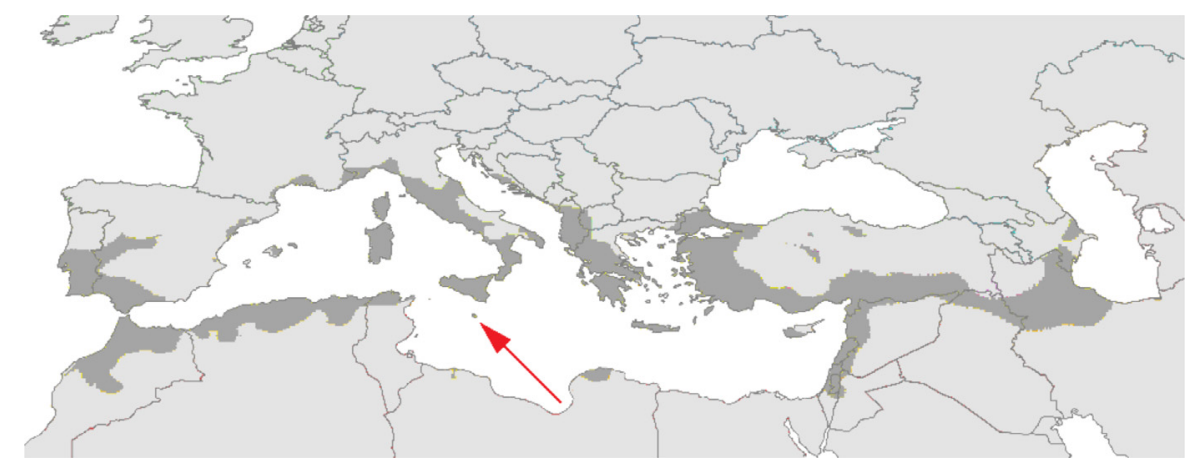

Fig. 1. Regions with a hot-summer Mediterranean climate (Csa) according to the Köppen climate classification and location of the Maltese archipelago in the central Mediterranean Basin (adapted from Ref. [30]).

Table 1. Information on the weather station as well as on the time period of data acquisition (data source: Ref. [8]).

\begin{tabular}{ll}
\hline Name of weather station & Luqa, Malta \\
\hline Latitude & $35.83^{\circ} \mathrm{N}$ \\
Longitude & $14.43^{\circ} \mathrm{E}$ \\
Altitude & $135 \mathrm{~m}$ a.s.l. \\
$\begin{array}{l}\text { Time period for temperature data } \\
\text { acquisition }\end{array}$ & $2000-2009$ \\
$\begin{array}{l}\text { Time period for solar radiation } \\
\text { data acquisition }\end{array}$ & $1991-2010$ \\
\hline
\end{tabular}

Table 2. Monthly and annual mean values of weather data for Luqa, Malta (data source: Ref. [8]).

\begin{tabular}{lllll}
\hline Month & $\begin{array}{l}\text { Air } \\
\text { temperature } \\
\left({ }^{\circ} \mathrm{C}\right)\end{array}$ & $\begin{array}{l}\text { Solar } \\
\text { irradiation } \\
\text { horizontal } \\
\left(\mathrm{kWh} / \mathrm{m}^{2}\right)\end{array}$ & $\begin{array}{l}\text { Relative } \\
\text { humidity } \\
(-)\end{array}$ & $\begin{array}{l}\text { Wind } \\
\text { speed } \\
(\mathrm{m} / \mathrm{s})\end{array}$ \\
\hline Jan & 12.4 & 77 & 0.77 & 4.0 \\
Feb & 11.9 & 95 & 0.75 & 4.4 \\
Mar & 13.7 & 140 & 0.76 & 4.5 \\
Apr & 15.8 & 178 & 0.74 & 4.7 \\
May & 19.6 & 218 & 0.69 & 4.0 \\
Jun & 23.7 & 222 & 0.61 & 3.3 \\
Jul & 26.5 & 232 & 0.60 & 3.2 \\
Aug & 26.5 & 202 & 0.64 & 3.2 \\
Sep & 23.9 & 157 & 0.71 & 3.4 \\
Oct & 21.1 & 124 & 0.76 & 3.1 \\
Nov & 17.5 & 87 & 0.74 & 3.8 \\
Dec & 14.3 & 72 & 0.75 & 4.4 \\
Year & 18.9 & 1801 & 0.71 & 3.8 \\
\hline
\end{tabular}

more precise, according to the Köppen climate classification, the Maltese climate is a hot-summer Mediterranean climate (Csa) [30]. The map in Figure 1 shows the Mediterranean regions that feature such a climate and the location of the Maltese archipelago in the central Mediterranean Basin.

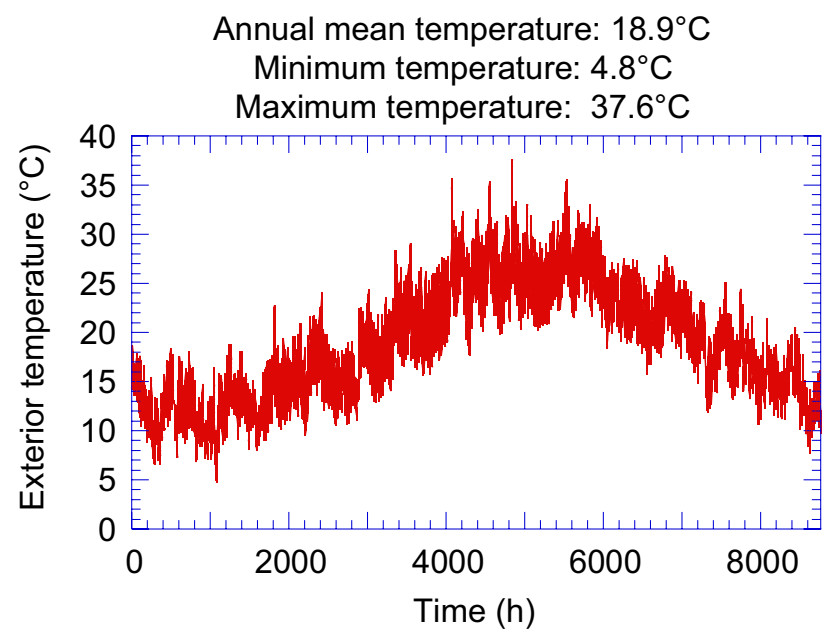

Fig. 2. Hourly air temperatures over a year of the weather data file for Luqa, Malta used in the present study (data source: Ref. [8]).

Table 1 displays information on the weather station in Luqa, Malta - which is the location of the Malta International Airport (MLA) - from where all weather data used in the present study were acquired. Table 1 also denotes the time period for the acquisition of original weather data. All weather data used in the present study were taken from a meteorological database called Meteonorm [8], which generates semi-synthetic hourly weather data sets in different formats - representing 'typical' years - that can be used as input files for building simulation purposes. Table 2 shows the monthly mean values of air temperature, solar irradiation horizontal, relative humidity and wind speed. Figure 2 displays the hourly air temperatures and Figure 3 shows the monthly mean values of global solar irradiation on vertical surfaces with different orientations as well as for a horizontal surface.

\subsection{Building energy simulation (WUFI ${ }^{\circledR}$ Plus)}

Building energy simulation is based on a thermodynamic, as well as a fluid-dynamic, network model and has become a valuable method not just for research but also for planning, building design and education purposes. A considerable number of these codes have been developed in recent 


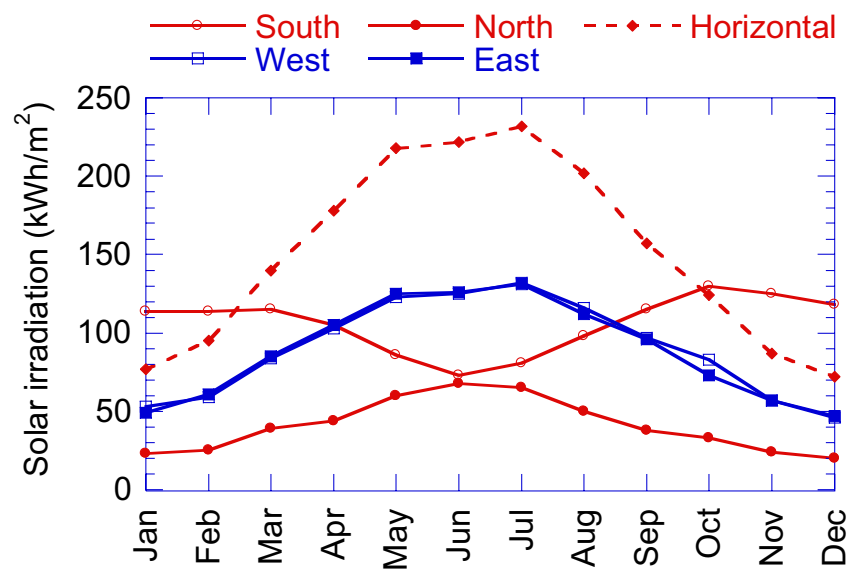

Fig. 3. Monthly mean values of global solar irradiation on vertical surfaces with different orientations as well as for a horizontal surface for Luqa, Malta (data source: Ref. [8]).

years [31]. An overview of the basic theory and application of this type of program is given in the standard work of Clarke [32]. Building energy simulation models typically employ one node per zone or room, corresponding to one lumped air temperature in each room. Because of the integrative approach of simultaneously processing all relevant energy transport paths, building energy simulation codes are powerful tools for the design of energy efficient buildings, and, not least because of that feature, are being increasingly used.

The external boundary conditions are given by the weather conditions - particularly air temperature and solar irradiances on façades and roofs - and the internal boundary conditions by the space use - such as the internal heat gains due to occupancy and appliances. Solar gains are calculated for each window depending on the respective solar irradiances, properties of glazings and shading devices. Ventilation gains or losses are, e.g. calculated based on predefined time schedules of air change rates. The transient heat transfer through the building envelope, but also the heat storage processes in the internal building elements, are taken into account by specifying the thickness and thermophysical properties of the materials used.

For most standard building simulations, the overall energy conservation equation is solved in time intervals of $1 \mathrm{~h}$, as internal changes are slow to occur, and can be well captured with this level of resolution. The simulation program WUFI ${ }^{\circledR}$ Plus v3.1.0.3 [33] developed by the Fraunhofer Institute for Building Physics in Germany was used in the present study, which additionally features the capability for dynamic hygrothermal simulation. However, this option - mainly developed for analysing and preventing moisture damage in buildings - was not employed because the present study focused on thermal comfort.

\subsection{Reference building model}

A reference building model was set up in WUFI ${ }^{\circledR}$ Plus v3.1.0.3 based on the assumption of a fully detached,
Table 3. Geometry and use of the reference case model.

\begin{tabular}{ll}
\hline Length $\times$ width $\times$ height $(\mathrm{m})$ & $20 \times 10 \times 2.8$ \\
\hline Gross floor area $\left(\mathrm{m}^{2}\right)$ & 200 \\
Gross volume $\left(\mathrm{m}^{3}\right)$ & 560 \\
Window to wall ratio $\mathrm{S} / \mathrm{W} / \mathrm{N} / \mathrm{E}(-)$ & $0.26 / 0 / 0.18 / 0$ \\
Area of internal walls $\left(\mathrm{m}^{2}\right)$ & $80 \mathrm{~m}^{2}$ \\
Use & Open space office \\
\hline
\end{tabular}

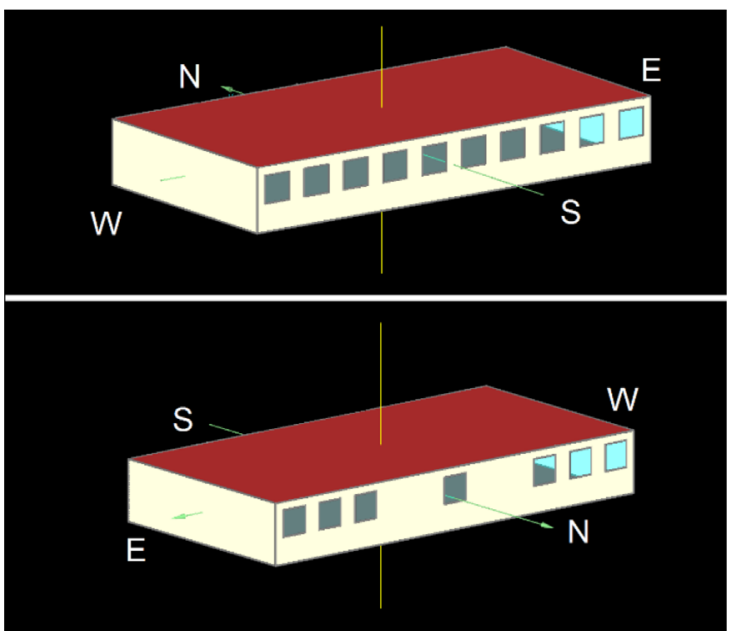

Fig. 4. Reference case WUFI ${ }^{\circledR}$ Plus v3.1.0.3 model.

cuboid-shaped, generic multi-storey building, where all façades were fully exposed to solar radiation and each storey had a gross floor area of $200 \mathrm{~m}^{2}$ (Tab. 3). Assuming exactly the same geometry, construction and use for each storey only one representative storey was modelled. Room temperatures in the storeys below and above the modelled storey were assumed to be identical to the modelled storey, thus representing adiabatic boundary conditions. The internal load "open space office" from the WUFI ${ }^{\circledR}$ Plus database was chosen, where heat and carbon dioxide releases from Monday to Friday are based on the German standard DIN 18599-100 [34]. Internal walls typical for the specified use (staircase, lift, toilets) were defined. The whole storey was modelled as a single zone having, therefore, only one operative room temperature. Table 4 shows the layer sequences of external and internal walls as well as floor slabs. Figure 4 displays the WUFI ${ }^{\circledR}$ Plus model.

Architecturally, the window wall ratios were 0.26 for the south and 0.18 for the north façade, while no windows were defined on the other façades. The thermal transmittances of the external walls $\left(U_{\text {wall }}\right)$ and the windows $\left(U_{\text {window }}\right)$ were specified as $0.54 \mathrm{~W} /\left(\mathrm{m}^{2} \cdot \mathrm{K}\right)$ and $1.2 \mathrm{~W} /$ $\left(\mathrm{m}^{2} \cdot \mathrm{K}\right)$, respectively. The total solar energy transmittance (g) of all windows was defined as 0.65 , while the frame factor was set equal to 0.85 .

In terms of ventilation, air change rates were chosen depending on the season as well as on the time of the day. In wintertime, the only goal of ventilation was to maintain a 
Table 4. Layer sequences of floor slabs as well as of external and internal walls of the reference case model.

\begin{tabular}{llllll}
\hline Assembly & Material & $\begin{array}{l}\text { Thickness } \\
(\mathrm{m})\end{array}$ & $\begin{array}{l}\text { Thermal } \\
\text { conductivity } \\
(\mathrm{W} /(\mathrm{m} \cdot \mathrm{K}))\end{array}$ & $\begin{array}{l}\text { Density } \\
\left(\mathrm{kg} / \mathrm{m}^{3}\right)\end{array}$ & $\begin{array}{l}\text { Specific } \\
\text { heat } \\
(\mathrm{J} /(\mathrm{kg} \cdot \mathrm{K}))\end{array}$ \\
\hline Floor slab & Tiles & 0.02 & 1.66 & 2453 & 702 \\
& Screed & 0.06 & 1.6 & 1970 & 850 \\
& Mineral wool & 0.03 & 0.043 & 115 & 850 \\
& Reinforced concrete & 0.20 & 2.3 & 2300 & 1000 \\
& Gypsum plaster & 0.01 & 0.2 & 850 & 850 \\
External wall & External plaster & 0.01 & 0.9 & 1360 & 850 \\
& Expanded polystyrene & 0.06 & 0.04 & 30 & 1500 \\
& Concrete block masonry & 0.18 & 1.6 & 2220 & 850 \\
& Gypsum plaster & 0.01 & 0.2 & 850 & 850 \\
& Gypsum plaster & 0.01 & 0.2 & 850 & 850 \\
& Concrete block masonry & 0.18 & 1.6 & 2220 & 850 \\
& Gypsum plaster & 0.01 & 0.2 & 850 & 850 \\
\hline
\end{tabular}

good level of indoor air quality, meaning to keep the carbon dioxide concentration - as a measure for indoor air quality - always below 1000 ppm during occupancy, which required 1.3 ACH. During summertime, nighttime ventilation was additionally employed in order to passively cool down the building structure so that on the following day a heat sink was available that could absorb thermal loads. Therefore, between mid-June and mid-September an air change rate of $4 \mathrm{ACH}$ was set from 10 p.m. to 7 a.m. All heat transfer coefficients at surfaces were kept constant at the default values corresponding to European standards, namely $7.7 \mathrm{~W} /\left(\mathrm{m}^{2} \mathrm{~K}\right)$ at internal surfaces $-3.2 \mathrm{~W} /\left(\mathrm{m}^{2} \mathrm{~K}\right)$ for convection and $4.5 \mathrm{~W} /\left(\mathrm{m}^{2} \mathrm{~K}\right)$ for radiation - and $25 \mathrm{~W} /$ $\left(\mathrm{m}^{2} \mathrm{~K}\right)$ at external surfaces. When all windows were closed, an infiltration air change rate of $0.1 \mathrm{ACH}$ was assumed.

Variable shading devices for all windows with a reduction factor - which can also be understood as a solar transmittance $(\tau)$ - equal to 0.1 were employed, where the devices were closed if the interior temperature exceeded the predefined control temperature $\left(\theta_{c}\right)$ of $25^{\circ} \mathrm{C}$.

The initial temperature of all building components was set to $22^{\circ} \mathrm{C}$ (time step $t=0$ ), which corresponds roughly with the final room temperature at $t=8760 \mathrm{~h}$.

\subsection{Thermal comfort analysis}

Adaptive thermal comfort models have become widely accepted and have been increasingly used in recent years despite the fact that model differences in regulatory documents and minor uncertainties in applications still do exist [35]. In the present study, the adaptive model of the European standard EN 15251 [36] was employed for assessing thermal comfort, which refers to buildings without mechanical cooling systems and with openable windows. In this empirically derived adaptive thermal comfort concept, the range of acceptable operative room temperatures is defined as a function of an exponentially weighted running mean of the exterior temperature, where three categories - category I to category III - of different levels of thermal comfort are distinguished. For exterior running mean temperatures below $15^{\circ} \mathrm{C}$, the lower limits of the acceptable operative temperatures remain constant at $21^{\circ} \mathrm{C}$ (category I), $20^{\circ} \mathrm{C}$ (category II), and $19{ }^{\circ} \mathrm{C}$ (category III), respectively. Details are given in the European standard EN 15251 [36]. The number of hours outside each category was counted for each simulation case. For this purpose, a spreadsheet was programmed to count the number of hours outside each category for a given time series of operative room temperatures. Only office hours were used in this analysis. The operative room temperature is calculated in WUFI ${ }^{\circledR}$ Plus as the mean value of the air temperature and the mean radiant temperature in the room. The latter is defined as the area-weighted mean surface temperature of the enclosures (walls, windows, ceiling and floor). The influence of other room parameters such as, for example, the relative humidity on the adaptive thermal comfort is not included in the model utilised. This is an area of ongoing research [37] and no widely accepted adaptive thermal comfort models that include relative humidity exist as yet.

\subsection{Concept of parametric study}

In order to better understand the impact of input variables on thermal comfort and test the robustness of results, a parametric study was performed. The present study also shows how sensitive the results are to a change of certain input variables. Starting from the reference case described in Section 2.3, the straightforward and well-established one-factor-at-a-time (OFAT) method was used in order to show the effect of the variation of orientation, window wall ratio, glazing, thermal insulation, thermal mass, shading and nighttime ventilation on the level of thermal comfort that can be achieved. Input parameters were varied according to Table 5. When thermal mass was varied, a lightweight sandwich construction for the internal walls of gypsum board $(0.0125 \mathrm{~m})$, mineral wool $(0.05 \mathrm{~m})$ and gypsum board $(0.0125 \mathrm{~m})$ was assumed and in the case of 
Table 5. Reference case and variation of input data in the parametric study based on the principle one-factor-at-a-time and including 29 cases in total.

\begin{tabular}{|c|c|c|c|c|c|}
\hline \multirow[t]{2}{*}{ Parameter } & \multirow[t]{2}{*}{ Reference case } & \multirow[t]{2}{*}{ Case } & \multicolumn{3}{|c|}{ Variation } \\
\hline & & & 1 & 2 & 3 \\
\hline Orientation & South & $\mathrm{A}$ & West & North & East \\
\hline $\begin{array}{l}\text { Window wall ratio } \\
(\mathrm{S} / \mathrm{W} / \mathrm{N} / \mathrm{E}) \\
\end{array}$ & $0.26 / 0 / 0.18 / 0$ & $\mathrm{~B}$ & $0.13 / 0 / 0.18 / 0$ & $0.52 / 0 / 0.18 / 0$ & $0.78 / 0 / 0.18 / 0$ \\
\hline Glazing & $\begin{array}{l}\text { Modern double } \\
U=1.2 \mathrm{~W} /\left(\mathrm{m}^{2} \mathrm{~K}\right) \\
g=0.65\end{array}$ & $\mathrm{C}$ & $\begin{array}{l}\text { Single } \\
U=5.7 \mathrm{~W} /\left(\mathrm{m}^{2} \mathrm{~K}\right) \\
g=0.82\end{array}$ & $\begin{array}{l}\text { Old double } \\
U=3.0 \mathrm{~W} /\left(\mathrm{m}^{2} \mathrm{~K}\right) \\
g=0.77\end{array}$ & $\begin{array}{l}\text { Modern triple } \\
U=0.7 \mathrm{~W} /\left(\mathrm{m}^{2} \mathrm{~K}\right) \\
g=0.5\end{array}$ \\
\hline \multirow{3}{*}{ Shading device } & $\tau=0.1$ & $\mathrm{Da}$ & $\tau=0.2$ & $\tau=0.3$ & $\tau=0.4$ \\
\hline & $\overline{\theta_{c}}=25^{\circ} \mathrm{C}$ & $\mathrm{Db}$ & $\theta_{c}=23^{\circ} \mathrm{C}$ & $\theta_{c}=27^{\circ} \mathrm{C}$ & $\theta_{c}=29^{\circ} \mathrm{C}$ \\
\hline & Variable & $\mathrm{Dc}$ & \multicolumn{3}{|c|}{ Fixed overhang (south façade only) } \\
\hline Thermal insulation & $0.06 \mathrm{~m}$ & $\mathrm{E}$ & $0.0 \mathrm{~m}$ & $0.03 \mathrm{~m}$ & $0.09 \mathrm{~m}$ \\
\hline \multirow[b]{2}{*}{ Nighttime ventilation } & $4 \mathrm{ACH}$ & $\mathrm{Fa}$ & $0 \mathrm{ACH}$ & $2 \mathrm{ACH}$ & $6 \mathrm{ACH}$ \\
\hline & 10 p.m. to 7 a.m. & $\mathrm{Fb}$ & 6 p.m. to 7 a.m. & 8 p.m. to 7 a.m. & 12 p.m. to 7 a.m. \\
\hline Thermal mass & $\begin{array}{l}\text { Massive internal } \\
\text { walls }\end{array}$ & $G$ & $\begin{array}{l}\text { Lightweight } \\
\text { internal walls }\end{array}$ & All walls lightweight & \\
\hline
\end{tabular}

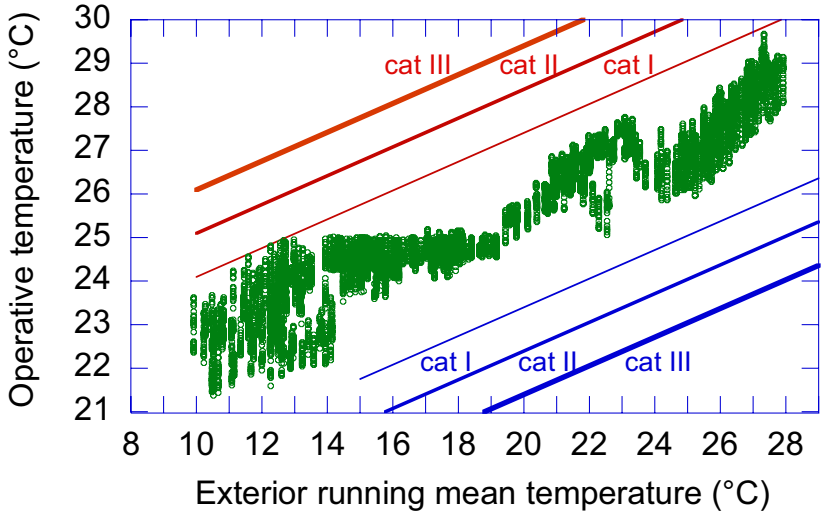

Fig. 5. Thermal comfort analysis according to EN15251 [36] shows that the operative room temperature is always within the category I boundaries in the reference case.

external walls, concrete block masonry was replaced by gypsum board. In the case of a fixed overhang, only the south façade was shaded. The north façade was left unshaded.

\section{Results}

Figure 5 shows the thermal comfort analysis of the reference case simulation results based on EN 15251 [36]. It can be seen that with the input parameter set of the reference case, during the course of the whole year the freerunning operative room temperature is always within the
Operative temperature:

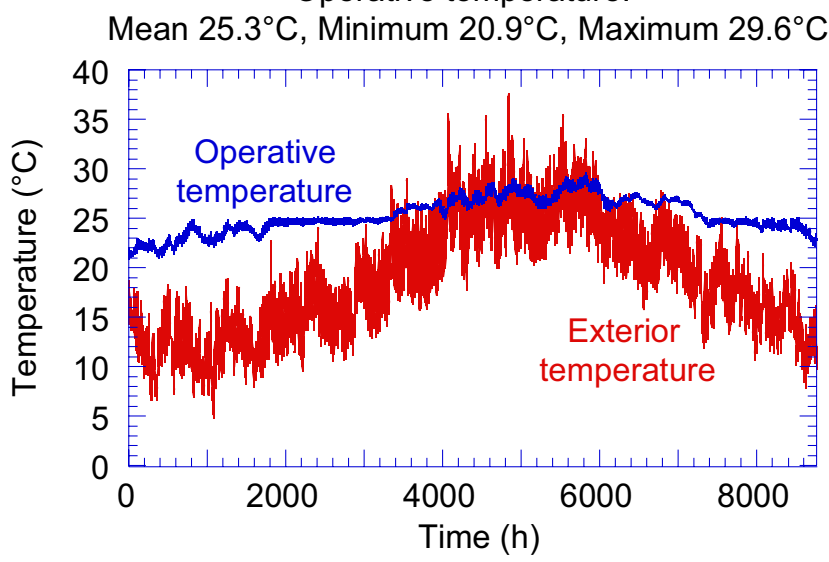

Fig. 6. Operative room temperature of reference case and exterior temperature as a function of time.

limits of category I. This means that a high level of thermal comfort is achieved with neither heating nor cooling. This well-designed or "ideal" building - from the point of view of energy and thermal comfort - was, therefore, taken as the reference for the parametric study.

Figure 6 displays the operative room temperature of the reference case and the exterior temperature during the course of the simulation time period of 1 year. The range of exterior temperature is from 4.8 to $37.6^{\circ} \mathrm{C}$, while the range of temperature in the interior of the reference building is between 20.9 and $29.6^{\circ} \mathrm{C}$. This range of interior temperatures has been shown to be sufficient to ensure 

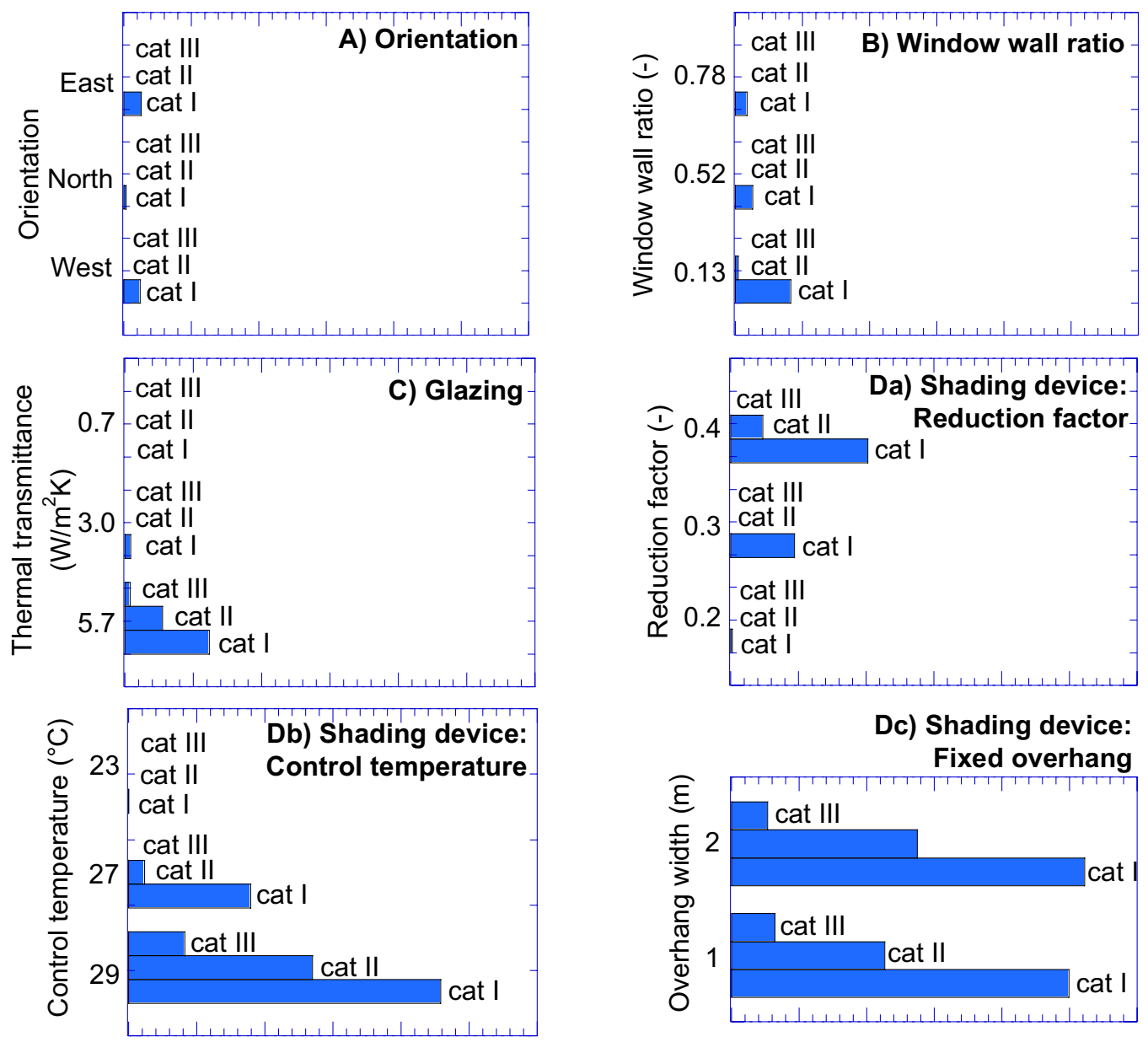

Dc) Shading device:
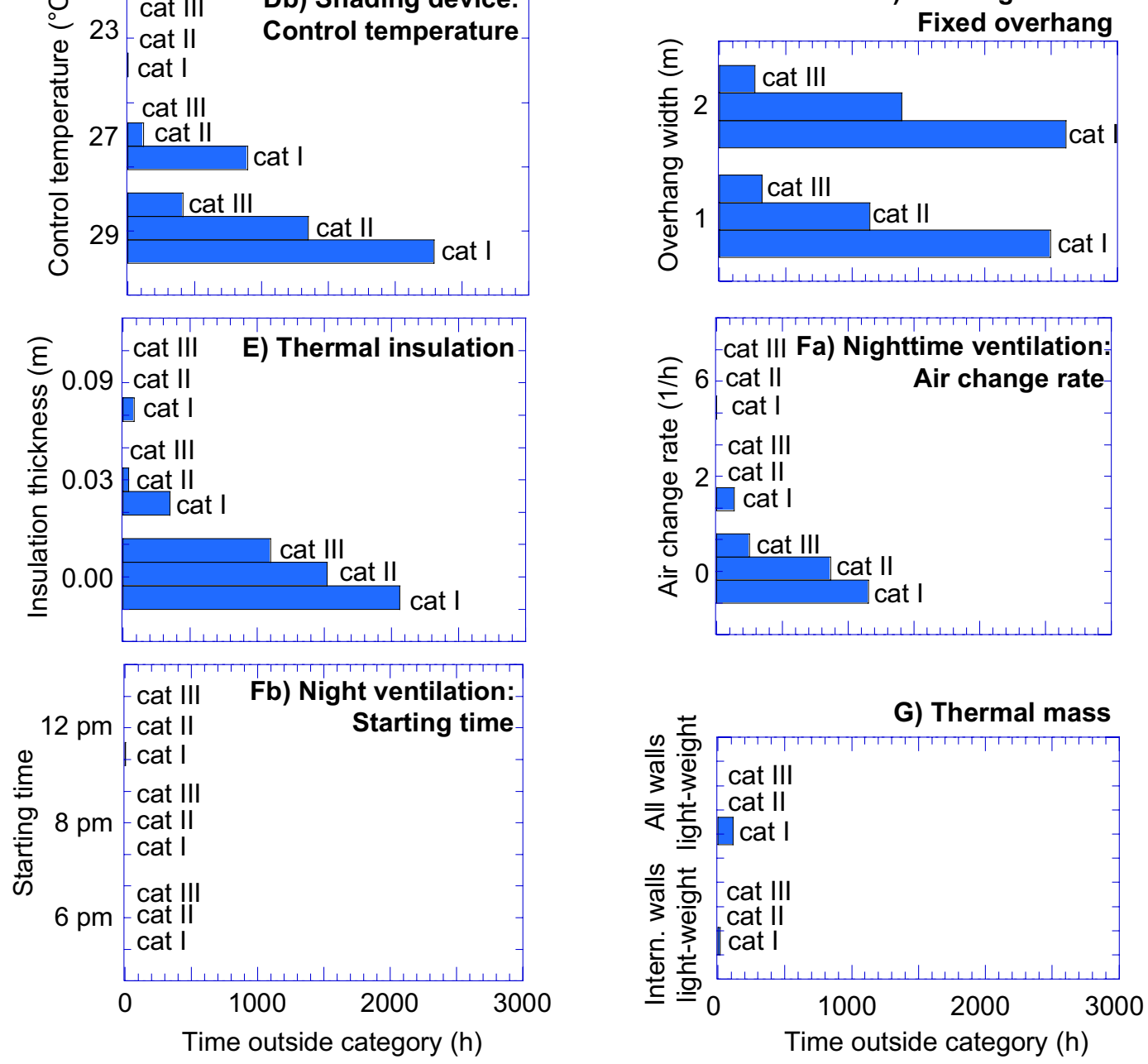

Fig. 7. Building energy simulation results show the effect of orientation, window wall ratio, glazing, thermal insulation, thermal mass, shading and nighttime ventilation on the time outside a certain comfort category according to EN15251 [36]. 

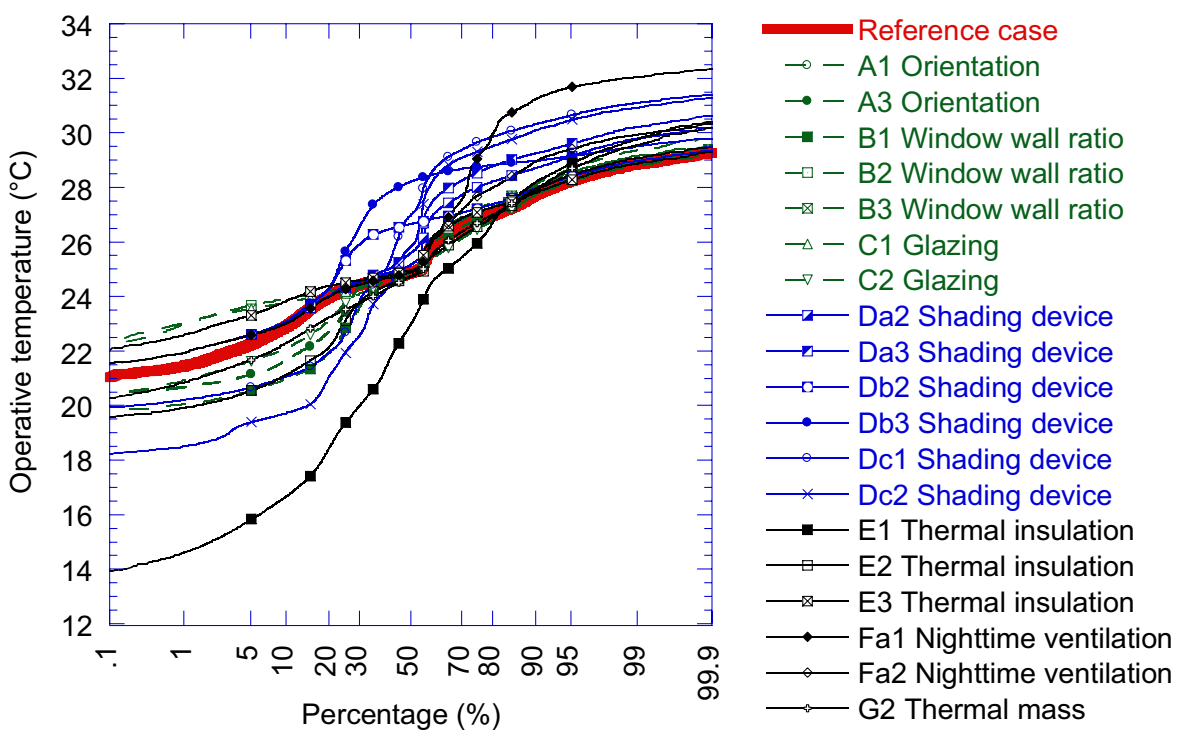

Fig. 8. Cumulative frequency distributions of operative temperatures of reference case and 19 other cases.

category I thermal comfort as indicated in Figure 5. These presented results confirm the adequacy of the reference case chosen as an optimal solution for thermal comfort. On this basis, the sensitivity of the thermal comfort results to changes in the variables given in Table 5 was analysed.

Figure 7 shows the main results obtained with the one-factor-at-a-time parametric study. The effect of orientation, window wall ratio, glazing, shading, thermal insulation, nighttime ventilation and thermal mass on the number of hours outside a certain comfort category can be seen. The reference case is not displayed in this figure.

Orientation does not have a crucial effect on the indoor thermal comfort in this case. Eastern and Western orientations give the most hours outside of category I but still category II and category III conditions are attained over practically all hours of the year. The Northern orientation is close to the optimum as it provides category I comfort during almost all of the year.

Window to wall ratio on the southern façade has a more predominant effect on thermal comfort compared to orientation. This is particularly true for ratios of 0.13 where solar gains are so limited that during the winter period, indoor temperatures outside category I increase significantly. During summer, where thermal gains are ideally avoided, using larger window to wall ratios do not impose a large penalty on the number of comfort hours. This might be contrary to expectations for such a warm climate but is due to effective shading and nighttime cooling.

Increasing thermal transmittance of glazing tends to cause a reduction in the number of comfort hours, particularly if category I is sought. Thermal transmittances below $3 \mathrm{~W} /\left(\mathrm{m}^{2} \mathrm{~K}\right)$ tend to give comfortable category I condition.

The reduction factor for shading devices shows the importance of considering shading. Increasing the reduction factor decreases comfort conditions with more temperature points falling outside category I. Control temperatures and overhang width are also shown to be crucial parameters to ensure category I conditions. For the former, control temperatures smaller than $27^{\circ} \mathrm{C}$ seem to be necessary, while for the latter, fixed overhangs on the southern façade seem to deteriorate comfort performance with most hours being outside of category I. The figures suggest to remove overhangs all together with the other conditions maintained optimal as for the reference case.

Thermal insulation levels show clear trends where the use of no thermal insulation tends to give large amount of hours outside category III. An insulation thickness of only $3 \mathrm{~cm}$ results in a significant increase of thermal comfort compared with no insulation.

Nighttime ventilation is shown to be necessary at least in small amounts of at least $2 \mathrm{ACH}$ (assuming constant convective heat transfer coefficients). The starting time of the nighttime ventilation is shown not be a crucial parameter in this respect.

Finally, the results for thermal mass indicate that the increase of thermal mass due to internal and external walls does not have a substantial effect on thermal comfort. It appears that the concrete slabs of the floor and ceiling already provide a significant contribution to the required thermal mass and, therefore, lightweight walls tend to still give acceptable levels of comfort.

Figure 8 displays the cumulative frequency distributions of operative temperatures of the reference case and 19 other cases. The nine cases, which deviated least from the reference case, are not shown in Figure 8. In winter, lowest operative temperatures occur in case E1 (no thermal insulation). In summer, highest operative temperatures occur in case Fa1 (no nighttime ventilation). In comparison with the reference case, case Dc2 (Fixed overhang, $w=2 \mathrm{~m}$ ) exhibits lower operative temperatures in wintertime (solar gains too low) and higher operative temperatures in summertime (solar gains too high). Compared with case DC2, case Dc1 (Fixed overhang, $w=1 \mathrm{~m}$ ) features even slightly higher operative temperatures in summertime, while performing better in wintertime. 


\section{Discussion}

Despite the relatively warm Maltese summer nights, passive cooling by nighttime ventilation was shown to be a key concept of passive design in this Mediterranean climate. This conclusion is in agreement with the findings of Michael et al. [27]. The heat capacity required for passive cooling by nighttime ventilation is easily available in Maltese buildings as local building construction materials typically feature soft stone masonry (globigerina limestone), now slowly replaced by HCB (Hollow Concrete Blockwork) and reinforced concrete slabs. All have attributes of high thermal inertia. Timber constructions are very uncommon, practically inexistent. The prevailing wind over the Maltese archipelago is the north-westerly, even though the strongest come from the NE. Wind speeds can be below $1 \mathrm{~m} / \mathrm{s}$ but on average are significantly higher than this, which basically represents favourable conditions for reliable nighttime cross-ventilation [8,38]. A shift of a few hours of the starting time of nighttime ventilation showed only a very minor impact on cooling performance. The reason for this is that before midnight temperature differences between interior and exterior are typically quite small and cooling is, therefore, not very effective. However, during the early morning hours, exterior temperatures are lowest and hence cooling potential is highest. The sensitivity to somewhat higher or lower air changes appears to be also quite limited.

Another key factor is effective variable external shading - low solar transmittances and smart control as well as appropriate window wall ratios. Both factors help to prevent the overheating of the building and keep the room temperature fluctuations small, which is a prerequisite for good thermal comfort.

The non-existent variability of fixed overhangs can lead to solar gains that are too high in summertime and too low in wintertime. Fixed overhangs are also disadvantageous with respect to daylighting, as the permanent reduction of daylight also applies when the sky is overcast and daylight is scarce - valuable daylight from the zenith region, where luminance is typically highest, is blocked. However, this is not so much a concern in a typical Mediterranean climate.

It was found that single glazing and - even more so no thermal insulation result in thermal discomfort in wintertime. One has to keep in mind that large glazed areas with high thermal transmittances can also cause thermal discomfort due to radiation exchange between a person and the glazed area as well as due to cold downdraught.

The building orientation had only a minor impact on overall performance in this case study. However, if the glazed area is positioned almost on one façade only, this might not apply.

One has to be aware that a large number of hours outside a category does not necessarily mean that it is impossible to reach a high level of thermal comfort with a certain parameter value - by means of adjusting other parameters as well comfort could possibly be improved. Therefore, each particular building has to be understood as a unique energy system in which the effect of input parameters is interconnected.
However, there are also limitations to passive design given, e.g., by the application of natural ventilation and the inherent stochastic nature of weather patterns and parameters - such as exterior temperature, direction and wind speed - meaning that air change rates can neither be predicted nor constantly maintained at a certain required value for ensuring indoor air quality or thermal comfort. These stochastic fluctuations can reduce the level of achievable thermal comfort and/or indoor air quality. By means of motor-driven openable controlled windows, system reliability might be improved, by using, for example, carbon dioxide concentration or exterior and interior temperature as input parameters for the control of daytime or nighttime ventilation, and/or hybrid ventilation concepts - mechanical ventilation during office hours to maintain indoor air quality. However, occupants and owners will decide in the very end what is still acceptable in terms of short-time discomfort and costs.

It has to be stressed that the effectiveness of nighttime ventilation as well as the building energy demand for heating and cooling in general can also be affected by microclimatic variables that depend on the urban morphology, which is known as urban overheating [39,40]. The urban heat island effect can be desirable in wintertime, where it can lead to a reduction of the heating demand, whereas in summertime, this is undesirable as cooling demand is increased and the potential for passive cooling by nighttime ventilation is decreased.

Limitations to the performance and applicability of the presented passive design concepts are also given by extreme weather conditions [40], the existing building stock, planning regulations, the knowhow of architects and engineers, the user behaviour and costs among others.

In a long-term perspective, global warming will change the climatic boundary conditions and the energy demand of buildings [39,41] and reduce the passive night cooling potential [42] also in Mediterranean climates, meaning that, e.g. shading and window to wall ratios become even more important. In view of climate warming, the building design strategies suitable for the current Mediterranean climate might be of interest and worth to be considered for presently colder climates.

The present study focused on optimising thermal comfort by means of passive design assuming neither artificial heating nor cooling. Other optimisation criteria such as total costs might lead to different solutions. However, the application of sophisticated passive design strategies includes the advantages of only minor investment and operational costs for HVAC equipment or even none at all while providing a high level of thermal comfort by means of a low-tech, robust, easy to maintain and usually well-accepted building.

\section{Conclusions}

This case study focuses on thermal comfort as an important factor of overall occupant satisfaction and demonstrates the potential and limitations of passive design strategies in the climate of the Maltese archipelago in the central Mediterranean Basin. By means of a parametric building 
energy simulation study and analysing the free-running operative room temperature, the impact of orientation, window to wall ratio, glazing, shading, thermal insulation, nighttime ventilation and thermal mass was shown employing the adaptive thermal comfort concept of the European standard EN 15251 [36] for buildings without mechanical cooling systems. Such a parametric study can also be understood as a sensitivity analysis by which the robustness of a passive design solution is investigated.

The present study demonstrates that in a well-designed building and by means of decent insulation ( $U_{\text {wall }}=$ $0.54 \mathrm{~W} /\left(\mathrm{m}^{2} \cdot \mathrm{K}\right)$ ), double glazing, variable shading devices and passive cooling by nighttime ventilation a high level of thermal comfort is achievable in the Mediterranean climate of the Maltese archipelago using only very minor amounts of energy for heating and cooling or possibly even none at all.

The authors acknowledge and thank the Faculty for the Built Environment at the University of Malta for hosting one of the authors as a visiting professor. We also thank the Fraunhofer Institute for Building Physics (IBP) in Germany for their support.

\section{References}

1. Directive 2010/31/EU of the European Parliament and of the Council of 19 May 2010 on the Energy Performance of Building, https://ec.europa.eu/energy/en/topics/energy-ef ficiency/buildings (retrieved 20 Apr. 2018)

2. Estimated Population by Locality 31st March, 2014, Government of Malta, 16 May 2014

3. Census of Population and Housing 2011, National Statistics Office, Malta, 2012, https://web.archive.org/web/ 20131203033602/http://www.nso.gov.mt/site/page.aspx? pageid $=588$ (retrieved 30 Apr. 2018)

4. J.P. González, C. Yousif, Prioritising energy efficiency measures to achieve a zero net-energy hotel on the island of Gozo in the central Mediterranean, Energy Procedia 83, 50 (2015)

5. An energy roadmap - towards achieving decarbonization for the Maltese Islands: analysis for a cost-effective and efficient heating and cooling, Ministry for Energy and Health, Malta, 2015

6. Energy Efficiency Directive: Article 4-Building Renovation, Malta's Long-Term Strategy for Mobilising Investment in the Renovation of the National Stock of Residential and Commercial Buildings, Malta, Nov. 2017

7. Minimum Energy Performance Requirements for Buildings in Malta, Technical Document F, Part 1, Building Regulation Office, Ministry for Transport and Infrastructure, Malta, 2015, https://secure2.gov.mt/epc/legislation?l=1 (retrieved 20 Apr. 2018)

8. Meteonorm v7.2.4, Software, Global meteorological database for engineers, planners and education, Meteotest, Berne, Switzerland, 2018

9. S.P. Borg, N.J. Kelly, K. Rizzo, Modelling and simulating the effects of the use of insulated building fabric in a multi-storey Maltese residential building, Sustainable Energy 2012: The ISE Annual Conference, 21 Feb. 2012, Qawra, Malta

10. T.F. Caruana, The effect of different glazing apertures on the thermal performance of Maltese buildings, M. Sc. disserta- tion, Institute for Sustainable Energy, University of Malta, Malta, 2015

11. D. Gatt, C. Yousif, Zero $\mathrm{CO}_{2}$ buildings - how low can we go: a case study of a small hotel in Gozo, Sustainable Energy 2016: The ISE Annual Conference, 4 Oct. 2016, University of Malta, Valletta Campus, Malta, pp. 30-37

12. D. Micallef, V. Buhagiar, S.P. Borg, Cross-ventilation of a room in a courtyard building, Energy Build. 133, 658 (2016)

13. V. Buhagiar, P. Jones, Thermal performance of historic buildings in Malta: the use of prediction models as design tools for refurbishment, Teaching in Architecture (TIA) Conference, Florence, Italy, July 2000

14. V. Buhagiar, P. Jones, Exploiting natural ventilation for renovation of historic buildings in an urban context, Passive 63 Low Energy Architecture PLEA2006, Geneva, Switzerland

15. X. Chen, H. Yang, W. Zhang, Simulation-based approach to optimize passively designed buildings: a case study on a typical architectural form in hot and humid climates, Renew. Sustain. Energy Rev. 82, 1712 (2018)

16. X. Gong, Y. Akashi, D. Sumiyoshi, Optimization of passive design measures for residential buildings in different Chinese areas, Build. Environ. 58, 46 (2012)

17. N.K. Khambadkone, R. Jain, A bioclimatic analysis tool for investigation of the potential of passive cooling and heating strategies in a composite Indian climate, Build. Environ. 123, 469 (2017)

18. W.A. Friess, K. Rakhshan, A review of passive envelope measures for improved building energy efficiency in the UAE, Renew. Sustain. Energy Rev. 72, 485 (2017)

19. S. Mirrahimi, M.F. Mohamed, L.C. Haw, N.L.N. Ibrahim, W.F. M. Yusoff, A. Aflaki, The effect of building envelope on the thermal comfort and energy saving for high rise buildings in hothumid climate, Renew. Sustain. Energy Rev. 53, 1508 (2016)

20. M. Santamouris, D. Kolokotsa, Passive cooling dissipation techniques for buildings and other structures: the state of the art, Energy Build. 57, 74 (2013)

21. N. Artmann, R.L. Jensen, H. Manz, P. Heiselberg, Experimental investigation of heat transfer during night-time ventilation, Energy Build. 42, 366 (2010)

22. N. Artmann, H. Manz, P. Heiselberg, Climatic potential for passive cooling of buildings by night-time ventilation in Europe, Appl. Energy 84, 187 (2007)

23. N. Artmann, H. Manz, P. Heiselberg, Parameter study on performance of building cooling by night-time ventilation, Renew. Energy 33, 2589 (2008)

24. C.M. Silva, M.G. Gomes, M. Silva, Green roofs energy performance in Mediterranean climate, Energy Build. 116, 318 (2016)

25. F. Ascione, N. Bianco, F. de Rossi, R.F. De Masi, G.P. Vanoli, Concept, design and energy performance of a net zero-energy building in Mediterranean climate, Procedia Eng. 169, 26 (2016)

26. A. Buonomano, U. Montanaro, A. Palombo, M. Vicidomini, NZEBs in Mediterranean climates: energy design and optimization for a non-residential building, Energy Procedia 82,458 (2015)

27. A. Michael, D. Demosthenous, M. Philokyprou, Natural ventilation for cooling in Mediterranean climate: a case study in vernacular architecture of Cyprus, Energy Build. 144, 333 (2017)

28. A. Salvati, H. Coch, M. Morganti, Effects of urban compactness on the building energy performance in the Mediterranean climate, Energy Procedia 122, 499 (2017) 
29. D. Mora, C. Carpino, M. De Simone, Behavioral and physical factors influencing energy building performances in Mediterranean climate, Energy Procedia 78, 603 (2015)

30. M.C. Peel, B.L. Finlayson, T.A. McMahon, Updated world map of the Köppen-Geiger climate classification, Hydrol. Earth Syst. Sci. 4, 439 (2007)

31. Building Energy Software Tools Directory, U.S. regional affiliate of the International Building Performance Simulation Association (IBPSA), https://www.buildingenergysoft waretools.com (retrieved May 5, 2018)

32. J.A. Clarke, Energy simulation in building design, Butterwoth-Heinemann, Oxford, 2001

33. WUFI ${ }^{\circledR}$ Plus v3.1.0.3, Software, Thermal, energy and moisture simulation of buildings, Fraunhofer Institute for Building Physics IBP, Valley, Germany, 2017

34. German standard DIN V 18599 Energetische Bewertung von Gebäuden - Berechnung des Nutz-, End- und Primärenergiebedarfs für Heizung, Kühlung, Lüftung, Trinkwarmwasser und Beleuchtung, Deutsches Institut für Normung e. V., Berlin, Germany, 2009

35. S. Carlucci, L. Baia, R. de Dear, L. Yang, Review of adaptive thermal comfort models in built environmental regulatory documents, Build. Environ. 137, 73 (2018)
36. European Standard EN 15251, Indoor Environmental Input Parameters for Design and Assessment of Energy Performance of Buildings Addressing Indoor Air Quality, Thermal Environment, Lighting and Acoustics, 2012

37. M. Vellei, M. Herrera, D. Fosas, S. Natarajan, The influence of relative humidity on adaptive thermal comfort, Build. Environ. 124, 171 (2017)

38. D. Micallef, D. Bounaudet, R.N. Farrugia, S.P. Borg, V. Buhagiar, T. Sant, Characterisation of wind-driven ventilation in complex terrain conditions, International Conference for Wind Engineering, Prague, 2018

39. M. Santamouris, On the energy impact of urban heat island and global warming on buildings, Energy Build. 82, 100 (2014)

40. M. Santamouris, D. Kolokotsa, On the impact of urban overheating and extreme climatic conditions on housing, energy, comfort and environmental quality of vulnerable population in Europe, Energy Build. 98, 125 (2015)

41. M. Christenson, H. Manz, D. Gyalistras, Climate warming impact on degree-days and building energy demand in Switzerland, Energy Convers. Manag. 47, 671 (2006)

42. N. Artmann, D. Gyalistras, H. Manz, P. Heiselberg, Impact of climate warming on passive night cooling potential, Build. Res. Inform. 36, 111 (2008)

Cite this article as: H. Manz, D. Micallef, S.P. Borg and V. Buhagiar: A parametric building energy simulation case study on the potential and limitations of passive design in the Mediterranean climate of Malta. Sust. Build. 3, 4 (2018). 